\title{
Meiofauna as food source for small-sized demersal fish in the southern North Sea
}

\author{
Sabine Schückel · Anne F. Sell • Terue C. Kihara • \\ Annemarie Koeppen · Ingrid Kröncke • \\ Henning Reiss
}

Received: 18 December 2011/Revised: 25 June 2012/ Accepted: 29 June 2012/Published online: 20 July 2012

(C) Springer-Verlag and AWI 2012

\begin{abstract}
Meiofauna play an essential role in the diet of small and juvenile fish. However, it is less well documented which meiofaunal prey groups in the sediment are eaten by fish. Trophic relationships between five demersal fish species (solenette, goby, scaldfish, dab $<20 \mathrm{~cm}$ and plaice $<20 \mathrm{~cm}$ ) and meiofaunal prey were investigated by means of comparing sediment samples and fish stomach contents collected seasonally between January 2009 and January 2010 in the German Bight. In all seasons, meiofauna in the sediment was numerically dominated by nematodes, whereas harpacticoids dominated in terms of
\end{abstract}

Communicated by Heinz-Dieter Franke.

S. Schückel · I. Kröncke · H. Reiss

Department for Marine Research, Senckenberg am Meer,

Südstrand 40, 26382 Wilhelmshaven, Germany

S. Schückel $(\square)$

BIOConsult Schuchardt und Scholle GbR,

Reeder-Bischoff Str. 54, 28757 Bremen, Germany

e-mail: schueckel@bioconsult.de

\section{A. F. Sell}

Institute of Sea Fisheries, Johann Heinrich von Thünen-Institute, Palmaille 9, 22767 Hamburg, Germany

T. C. Kihara

DZMB, Senckenberg am Meer, Südstrand 44,

26382 Wilhelmshaven, Germany

\footnotetext{
A. Koeppen

Carl von Ossietzky University of Oldenburg,

H. Reiss

Faculty of Biosciences and Aquaculture,

University of Nordland, Postbox 1490,

8049 Bod $\varnothing$, Norway
}

Department of Biology and Environmental Sciences,

Carl-von-Ossietzky Str. 9-11, 26111 Oldenburg, Germany occurrence and biomass. Between autumn and spring, the harpacticoid community was characterized by Pseudobradya minor and Halectinosoma canaliculatum, and in summer by Longipedia coronata. Meiofaunal prey dominated the diets of solenette and gobies in all seasons, occurred only seasonally in the diet of scaldfish and dab, and was completely absent in the diet of plaice. For all fish species (excluding plaice) and in each season, harpacticoids were the most important meiofauna prey group in terms of occurrence, abundance and biomass. High values of Ivlev's index of selectivity for Pseudobradya spp. in winter and Longipedia spp. in summer provided evidence that predation on harpacticoids was species-selective, even though both harpacticoids co-occurred in high densities in the sediments. Most surficial feeding strategies of the studied fish species and emergent behaviours of Pseudobradya spp. and Longipedia spp. might have caused this prey selection. With increasing fish sizes, harpacticoid prey densities decreased in the fish stomachs, indicating a diet change towards larger benthic prey during the ontogeny of all fish species investigated.

Keywords Meiofauna - Flatfish · Gobiids · Harpacticoids · Prey selection

\section{Introduction}

The crucial importance of meiofauna (by definition animals passing through a $0.5-\mathrm{mm}$ or $1.0-\mathrm{mm}$ mesh sieve, but retained on a $63-\mu \mathrm{m}$ mesh, Gee 1989) as food for higher trophic levels in marine food webs has been extensively investigated (e.g. Sogard 1984; Fitzhugh and Fleeger 1985; Tipton and Bell 1988; Nelson and Coull 1989; Coull et al. 1995). Many fish species, such as flatfish and gobies, feed 
on meiofaunal species such as harpacticoid copepods, making this prey group an essential factor governing fish survival and growth, especially of the juvenile stages. Yet, insights into the functional details of this predator-prey relationship remain to be explored, including, for example, feeding behaviour and predation impacts on the meiofauna community in the sediments.

Meiofauna communities consist of a great diversity of species, with only a few numerically dominant groups, foremost nematodes and harpacticoid copepods (Gee 1989). Nematodes are usually much more abundant in the sediments than harpacticoids. However, this numerical dominance of nematodes is rarely reflected in the diets of meiobenthivorous fish. Some of these fish species prey almost exclusively on harpacticoid copepods, excluding almost all other meiofaunal prey available (Coull 1990; Magnhagen et al. 2007). Comparative studies relating fish diets to meiofaunal prey in the sediments are rare (Alheit and Scheibel 1982; Sogard 1984; McCall 1992), resulting in a general lack of detailed information about prey selection or avoidance on meiofauna, especially with regard to the distribution and abundance of potential meiofaunal prey in the sediment at relevant temporal and spatial scales.

In this context, it has been argued (e.g. Gee 1989; Coull 1990) that feeding on harpacticoids appears to be highly selective. For instance, Alheit and Scheibel (1982) found selective feeding on Longipedia helgolandica Klie 1949 in a shallow lagoon of Bermuda. Sibert (1979) mentioned that Harpacticus uniremis Krøyer 1842 was consumed by salmon fry in British Columbia (Canada) in greater proportions than predicted from its abundance in the sediments, and Hicks (1984) found that juvenile flatfish feeding on intertidal sandflats in New Zealand fed exclusively on the harpacticoid Parastenhelia megarostrum.

Most habitats contain a variety of harpacticoid species, which may differ greatly in size, morphology, behaviour and microhabitat utilization (Hicks and Coull 1983). However, despite this diversity of potential harpacticoid prey species in the sediments, fish predators forage selectively. Selectivity in feeding behaviour has been experimentally investigated in small and juvenile fish (Feller et al. 1990; Aarnio 2000; Spieth et al. 2010), but the relative abundance of apparently preferred harpacticoid prey species in the field has not been taken into account for (Ellis and Coull 1989; Feller et al. 1990; Aarnio 2000). Consequently, essential knowledge whether feeding on harpacticoid prey is species-selective or merely on the most abundant harpacticoid species in the field is absent.

Therefore, the first aim of the present study was to investigate the general role of meiofauna in the sediment as a prey source for different small-sized demersal fish species. For this purpose, the seasonal variability of stomach contents of solenette Buglossidium luteum (Risso 1810), the sand goby Pomatoschistus minutus (Pallas 1770), scaldfish Arnoglossus laterna (Walbaum, 1792), common dab Limanda limanda L. 1758 and plaice Pleuronectes platessa L. 1758 caught in a study area ("Box A") in the German Bight was analysed and related to size and species composition patterns of meiofauna obtained from benthos samples from the same location. Secondly, the occurrence of and the factors leading to prey selectivity were examined by comparing harpacticoid copepod species and size composition in both the fish diets and the sediment samples.

\section{Materials and methods}

\section{Study area}

The study area is located in the German Bight about 25 nautical miles north-west of the Isle of Helgoland and is part of the "German small-scale bottom trawl survey" (GSBTS; "Box A"; Ehrich et al. 2007) (Fig. 1). The mean depth of this area is $39 \mathrm{~m}$, and water temperatures follow a seasonal cycle with monthly means between 4 and $17{ }^{\circ} \mathrm{C}$. Temporary stratification occurs during summer, whereas the water column is otherwise well mixed. Sediments in the study area consist of $>20 \%$ mud $(<63 \mu \mathrm{m}$ fraction) in the south-west, gradually decreasing towards the north-east (0-5\% mud). The remainder of the sediments consists of sand ( $>63 \mu \mathrm{m}$ fraction) (Ehrich et al. 2007).

\section{Sampling and sample treatment}

Between January 2009 and January 2010, fish and meiofauna samples were obtained on research cruises with F.R.V. Walther Herwig III (January and July) and R.V. Senckenberg (May and October). With the exception of January 2009 (when only fish sampling was possible), fish samples were always taken at the same site and at the same time as the meiofauna samples. A total of 48 randomly assigned stations were sampled during daylight.

\section{Meiofauna sampling}

For meiofauna, two sediment samples were taken at each station using a $0.1 \mathrm{~m}^{2}$ van Veen grab (only one in October because of stormy weather), as the multicorer did not close properly in the study area. The grab penetrated the sediment at a moderate speed; therefore, water flow through the corer was relatively unobstructed, and the bow wave was modest.

By penetrating the first 5 -cm sediment $\left(44.0 \mathrm{~cm}^{3}\right)$ of one grab bucket with a cylindrical corer (diameter, $3.35 \mathrm{~cm}$ ), 
Fig. 1 Location and depth of the study area in the North Sea

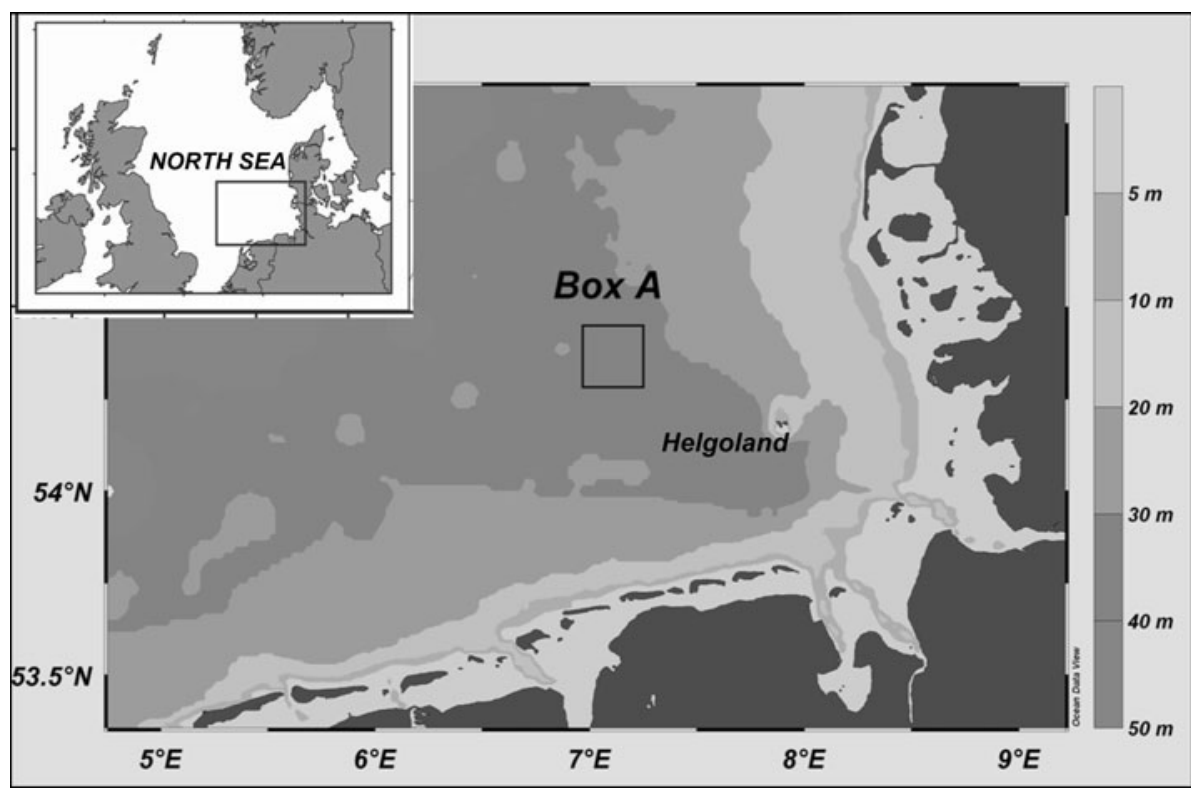

a subsample $\left(8.80 \mathrm{~cm}^{2}\right)$ was taken to analyse the meiofauna community structure. In total, 69 sediment cores (18 cores in May, 22 cores in July, 9 cores in October and 20 cores in January 2010) were taken. Each core content was fixed on board in $10 \%$ unbuffered formalin. In the laboratory, the fixed samples were washed through a sieve of $40-\mu \mathrm{m}$ mesh size with filtered tap water.

Meiofauna and organic matter were extracted from sediment by gravity centrifugation with a colloidal silica polymer $\left(\rho=1.17\right.$ Levasil $\left.^{\circledR} 200 / 40 \%\right)$ as flotation medium and kaolin to cover the heavier particles (McIntyre and Warwick 1984). The centrifugation was repeated three times at 4,000 rpm for $6 \mathrm{~min}$, respectively. After each centrifugation, the supernatant was rinsed with tap water in a $40-\mu \mathrm{m}$ sieve. The residual organic matter was transferred in a Bengal rose-stained $10 \%$ formalin solution. Stained organisms were identified to lowest possible taxonomic level and counted separately. Harpacticoids similar in morphology were separated and fixed in glycerol on a prepared glass slide. Identification to species level was conducted using a Leitz Dialux 22 microscope.

To obtain meiofaunal biomass data, all specimens (except harpacticoids and nematodes) were weighed wet to $0.0001 \mathrm{~g}$ precision. Biomass of harpacticoid copepods and nematodes was determined from volume calculations. From each species, the length $\times$ maximum width squared (in $\mathrm{mm}$ ) was calculated and multiplied with a conversion factor to give body volumes in nanolitre. For the nematodes, a common factor of 530 was applied (Warwick and Price 1979). For the copepods, each species was categorized visually into one of eight body forms, and conversion factors were applied which were derived from scale models in plasticene (see McIntyre and Warwick 1984). The proportion of total biomass attributable to each species was calculated by multiplying the total numbers present by the adult body volume, assuming that the size distribution relative to the size of the adult is the same for each species, as is the conversion factor from volume to biomass.

\section{Fish sampling}

Fish sampling was performed with the Chalut á Grande Ouverture Verticale-GOV (except May and October)and a standardized 2-m beam trawl. The GOV is the standard gear of the international bottom trawl survey in the North Sea (ICES 2009). The net opening was ca. $20 \mathrm{~m}$ wide and ca. $5 \mathrm{~m}$ high. Mesh size gradually decreased from 200 to $50 \mathrm{~mm}$ and a codend liner of 20-mm mesh opening (for details on the rigging see ICES 2009). The GOV trawl was towed 30 min with a constant speed of four knots over ground. Towing time started with bottom contact and vertical stabilization of the net opening.

The 2-m beam trawl carried a chain matt to prevent catching boulders and to enhance catch efficiency. It was fitted with a $20-\mathrm{mm}$ stretched mesh and a codend liner of 4-mm knotless mesh. A detailed description of the beam trawl construction is given in Jennings et al. (1999). A SCANMAR depth sensor was attached to its top just behind the steel beam to determine the exact time and position of contact with the seabed. From the moment of contact with the seabed, the beam trawl was towed with a speed of 1.5-2 knots for 5 min.

From each haul, all individuals of B. luteum, P. minutus, A. laterna, L. limanda and P. platessa caught were counted, total length to the nearest $\mathrm{cm}\left(L_{\mathrm{T}}\right)$ was measured, and wet weighed $(M)$ was determined. For later stomach 
analysis, if possible, a maximum of 35 individuals per species were frozen at $-20^{\circ} \mathrm{C}$.

\section{Stomach analysis}

Because digestive enzymes in the stomachs still work after the death of a fish, a 30-min limit for preparation and weighing was applied after having the nets on board. Only the fish stomachs of the GOV hauls were immediately removed on board and frozen at $-20^{\circ} \mathrm{C}$, whereas fish caught by the beam trawl were frozen whole without being dissected. In the laboratory, these fish were thawed, measured $\left(L_{\mathrm{T}}\right)$ and weighed $(M)$ again before stomachs were removed.

In the laboratory, the contents of each stomach were rinsed in fresh water, and the prey items contained were divided into macro- and meiofaunal prey. For the macrofauna, each prey item was identified to lowest taxonomic level possible and counted. Reliable biomass data for each macrofaunal prey species were obtained from infauna samples taken simultaneously in the field during the same surveys. For the meiofauna, each prey item was identified to lowest taxonomic level possible and counted. All harpacticoid copepods found in the stomachs were fixed in glycerol on a prepared glass slide and identified to the lowest taxonomic level possible and counted.

Meiofaunal prey in fish stomachs are often strongly degraded, and reliable biomass data can be difficult to obtain. Therefore, the mean individual weights obtained for each species from the simultaneously taken sediment samples in the field were used to convert prey abundance into prey biomass of the stomach content after visual categorization into prey size classes.

\section{Data analysis}

The stomach contents of 672 A. laterna $\left(L_{\mathrm{T}} 2-14 \mathrm{~cm}\right)$, 1,557 B. luteum $\left(L_{\mathrm{T}} 2-15 \mathrm{~cm}\right), 752$ P. minutus $\left(L_{\mathrm{T}}\right.$ 2-7 cm), 1,402 L. limanda $\left(L_{\mathrm{T}} 3-31 \mathrm{~cm}\right)$ and 698 $P$. platessa $\left(L_{\mathrm{T}} 10-65 \mathrm{~cm}\right)$ were analysed. No detailed analysis about fish predation on macrofaunal prey was made in the present study (predation on this group has been investigated by Schückel et al. 2011). Only the relative proportion of macrofaunal relative to meiofaunal prey was determined for each fish species. Individuals of $L$. limanda and $P$. platessa larger than $20 \mathrm{~cm} L_{\mathrm{T}}$ were not included in further analysis since their diets were dominated by macrofaunal prey (for details see Schückel et al. 2011). Empty stomachs were not included in the diet analysis (Table 1).

The relative importance of each meiofaunal prey item in the sediment cores and in the stomach contents was expressed by (1) frequency of occurrence $\left(I_{\mathrm{O}}\right)$, (2) percentage of numerical abundance $\left(I_{\mathrm{N}}\right)$ and $(3)$ percentage of biomass $\left(I_{\mathrm{W}}\right)$ for each season (Hyslop 1980).

To study the role of harpacticoids as prey source, the index of relative importance $\left(R_{\mathrm{I}}\right)$, which combines the relative contribution of a food item by number $\left(I_{\mathrm{N}}\right)$ and biomass $\left(I_{\mathrm{W}}\right)$, as well as by the percentage of frequency of occurrence $\left(I_{\mathrm{O}}\right)$, was calculated for each harpacticoid species in the sediment and in the stomachs, respectively, according to the following formula:

$R_{\mathrm{I}}=100 \times\left(\mathrm{AI} / \sum \mathrm{AI}\right)$,

where $\mathrm{AI}\left(\mathrm{AI}=I_{\mathrm{O}}+I_{\mathrm{N}}+I_{\mathrm{W}}\right)$ is the absolute importance index.

Seasonal differences of harpacticoid communities in the sediment, as well as in the fish diets, were assessed using multivariate statistics of the PRIMER software package (Plymouth Marine Laboratory, PRIMER v6). A BrayCurtis coefficient similarity matrix was calculated for both data sets consisting of non-transformed numerical abundances of each harpacticoid species recorded in the sediment cores and in the stomachs of each fish species. A one-way ANOVA (ANOSIM routine, test $R$ ) was performed to test the null hypothesis (i.e. no statistical differences in the sediment samples/fish diets between the seasons). Using a similarity of percentage analysis (SIMPER), characteristic harpacticoid species in the sediment and in the stomachs were identified for each season.

Table 1 Total number of stomachs analysed per season of the studied fish species

\begin{tabular}{|c|c|c|c|c|c|c|c|c|c|c|c|}
\hline \multirow{3}{*}{$\begin{array}{l}\text { Species } \\
\text { B. luteum }\end{array}$} & \multirow{3}{*}{$\begin{array}{l}\text { Species code } \\
\text { BUG }\end{array}$} & \multicolumn{10}{|c|}{ Total number of stomachs } \\
\hline & & \multicolumn{2}{|c|}{ January 2009} & \multicolumn{2}{|c|}{ May 2009} & \multicolumn{2}{|c|}{ July 2009} & \multicolumn{2}{|c|}{ October 2009} & \multicolumn{2}{|c|}{ January 2010} \\
\hline & & 350 & $(0)$ & 300 & (4) & 303 & $(8)$ & 297 & $(24)$ & 307 & $(92)$ \\
\hline P. minutus & POM & 153 & $(17)$ & 146 & $(26)$ & 37 & (11) & 334 & $(40)$ & 82 & $(17)$ \\
\hline A. laterna & ARN & 159 & $(1)$ & 31 & (3) & 71 & $(0)$ & 225 & $(56)$ & 186 & (120) \\
\hline L. limanda & LIM & 171 & $(60)$ & 50 & $(0)$ & 277 & $(51)$ & 166 & $(44)$ & 192 & (123) \\
\hline P. platessa & PLE & 81 & $(44)$ & 27 & $(0)$ & 100 & $(21)$ & 111 & $(43)$ & 37 & (3) \\
\hline$\sum$ & & & 914 & & 554 & & 788 & & 1,133 & & 804 \\
\hline
\end{tabular}

Number of empty stomachs is given in parentheses. Individuals of $L$. limanda and $P$. platessa with fish lengths $>20 \mathrm{~cm} \mathrm{LT}$ are excluded 
To assess the relationship between the abundance of harpacticoid prey species in the sediment and the harpacticoid prey in the stomachs, the Ivlev (1962) selection index $(E)$ was calculated per season:

$E=\left(r_{i}-p_{i}\right) \times\left(r_{i}+p_{i}\right)^{-1}$,

where $r_{i}$ is the relative abundance of prey species $i$ in the stomachs and $\mathrm{p}_{i}$ is the relative abundance of prey species $i$ in the sediment. $E$ ranges from -1 to +1 . Negative values indicate avoidance or inaccessibility of prey, and positive values indicate selection for a prey species. Non-selective feeding is indicated by values around zero.

Diet differences in harpacticoid prey selection between the studied fish species were tested using a one-way ANOVA based on numerical abundance data.

For examining size-related diet variations in harpacticoid prey selection, the percentage of frequency of occurrence and abundance of harpacticoid prey was determined per $L_{\mathrm{T}}$ for each fish species.

\section{Results}

Utilization of meiofauna by demersal fish

\section{General composition and seasonality of meiofauna}

In each season, harpacticoids were always the most frequently occurring meiofaunal prey group ( $I_{\mathrm{O}}$ values range from $47 \%$ in January to $57 \%$ in October), whereas nematodes were always the most abundant prey group $\left(I_{\mathrm{N}}\right.$ values range from $94 \%$ in July to $97 \%$ in October) (Table 2). Other frequently occurring meiofaunal groups were juvenile polychaetes in May $\left(I_{\mathrm{O}}=10 \%\right)$, copepodites in July $\left(I_{\mathrm{O}}=8 \%\right)$, juvenile bivalves in October and January $\left(I_{\mathrm{O}}=10\right.$ and $9 \%$, respectively) and ostracods in January $(6 \%)$, yet their numerical importance was low. In terms of biomass, harpacticoids and juvenile polychaetes were most dominant in each season (Table 2). Especially in summer, the meiofauna community was almost exclusively comprised by harpacticoids, doubling in biomass percentage $\left(I_{\mathrm{W}}=92 \%\right)$ compared to winter $\left(I_{\mathrm{W}}=66 \%\right)$ and spring $\left(I_{\mathrm{W}}=46 \%\right)$. The second most dominant meiofaunal group during summer were copepodites, reaching their highest biomass, frequency of occurrence and abundance in July $\left(I_{\mathrm{W}}=3 \% ; I_{\mathrm{O}}=8 \% ; I_{\mathrm{N}}=1 \%\right.$, respectively).

\section{General composition and seasonality of fish diets}

In terms of numerical abundance, meiofauna dominated the diets of $B$. luteum and $P$. minutus in all seasons, but was found rather season-specific in the diets of A. laterna and L. limanda (Fig. 2). In contrast, there was a complete absence of meiofaunal prey in the stomachs of P. platessa of any of the investigated size classes. Concerning prey biomass in the fish diets, macrofaunal prey generally dominated. A dominance in biomass of meiofaunal prey was only found for B. luteum in both winters (January 2009 and 2010).

The most important meiofaunal prey group of B. luteum, $P$. minutus, A. laterna and L. limanda were harpacticoids (Table 3). Over the course of the season, meiofauna dominated the diet of B. luteum in terms of occurrence as well as abundance by more than $80 \%$ between January and July decreasing only slightly to about $60 \%$ in the following October. Among different meiofaunal groups, almost exclusively harpacticoids were found numerically, gravimetrically as well as in terms of occurrence in each

Table 2 Percentage of frequency of occurrence $\left(I_{\mathrm{O}}\right)$, numerical abundance $\left(I_{\mathrm{N}}\right)$ and biomass $\left(I_{\mathrm{W}}\right)$ of meiofauna groups found in the sediment cores $\left(8.80 \mathrm{~cm}^{2}\right)$ per season

\begin{tabular}{|c|c|c|c|c|c|c|c|c|c|c|c|c|}
\hline & \multicolumn{3}{|l|}{ May 09} & \multicolumn{3}{|l|}{ Jul 09} & \multicolumn{3}{|l|}{ Oct 09} & \multicolumn{3}{|l|}{ Jan 10} \\
\hline & $I_{\mathrm{O}}(\%)$ & $I_{\mathrm{N}}(\%)$ & $I_{\mathrm{W}}(\%)$ & $I_{\mathrm{O}}(\%)$ & $I_{\mathrm{N}}(\%)$ & $I_{\mathrm{W}}(\%)$ & $I_{\mathrm{O}}(\%)$ & $I_{\mathrm{N}}(\%)$ & $I_{\mathrm{W}}(\%)$ & $I_{\mathrm{O}}(\%)$ & $I_{\mathrm{N}}(\%)$ & $I_{\mathrm{W}}(\%)$ \\
\hline Harpacticoids & 55.5 & 1.8 & 46.5 & 55.2 & 3.9 & 92.2 & 57.1 & 1.2 & 57.9 & 46.5 & 3.8 & 66.5 \\
\hline Nematodes & 10.0 & 96.2 & 2.2 & 7.6 & 93.9 & 2.7 & 9.9 & 97.3 & 2.4 & 9.4 & 94.2 & 4.3 \\
\hline Polychaetes & 10.0 & 0.5 & 42.5 & 6.8 & 0.3 & $<0.1$ & 8.7 & 0.3 & 37.7 & 7.3 & 0.1 & 24.2 \\
\hline Bivalves & 8.7 & 0.5 & 0.4 & 7.2 & 0.3 & 0.6 & 9.9 & 0.6 & 0.3 & 9.3 & 0.1 & 1.1 \\
\hline Gastropods & - & - & - & 2.4 & 0.2 & $<0.1$ & - & - & - & 1.1 & $<0.1$ & 1.2 \\
\hline Ostracods & 0.6 & 0.1 & $<0.1$ & - & - & - & 1.1 & $<0.1$ & 0.2 & 6.3 & $<0.1$ & 0.3 \\
\hline Echinoderms & - & - & & 5.2 & $<0.1$ & 0.1 & - & - & - & 3.1 & $<0.1$ & 0.2 \\
\hline Kinorhynchs & 2.5 & 0.6 & 0.1 & 6.5 & $<0.1$ & 0.1 & 7.7 & 0.6 & 0.4 & 6.3 & $<0.1$ & 0.4 \\
\hline Harpacticoids copepodites & - & - & - & 8.0 & 1.1 & 3.4 & 2.2 & $<0.1$ & 0.7 & $<0.1$ & 0.2 & 1.5 \\
\hline Others & 14.6 & 0.9 & 8.0 & 9.2 & 0.3 & 1.0 & 5.6 & $<0.1$ & 0.2 & 10.9 & 0.4 & 2.3 \\
\hline$\sum$ of cores studied & 18 & & & 22 & & & 9 & & & 20 & & \\
\hline
\end{tabular}

Important values are marked in bold 
Fig. 2 Percentage of

a numerical abundance and

b biomass of meiofaunal and

macrofaunal prey in the diet of

A. laterna (ARN), B. luteum

(BUG), P. minutus (POM),

L. limanda (LIM) and

$P$. platessa (PLE) per season (a)
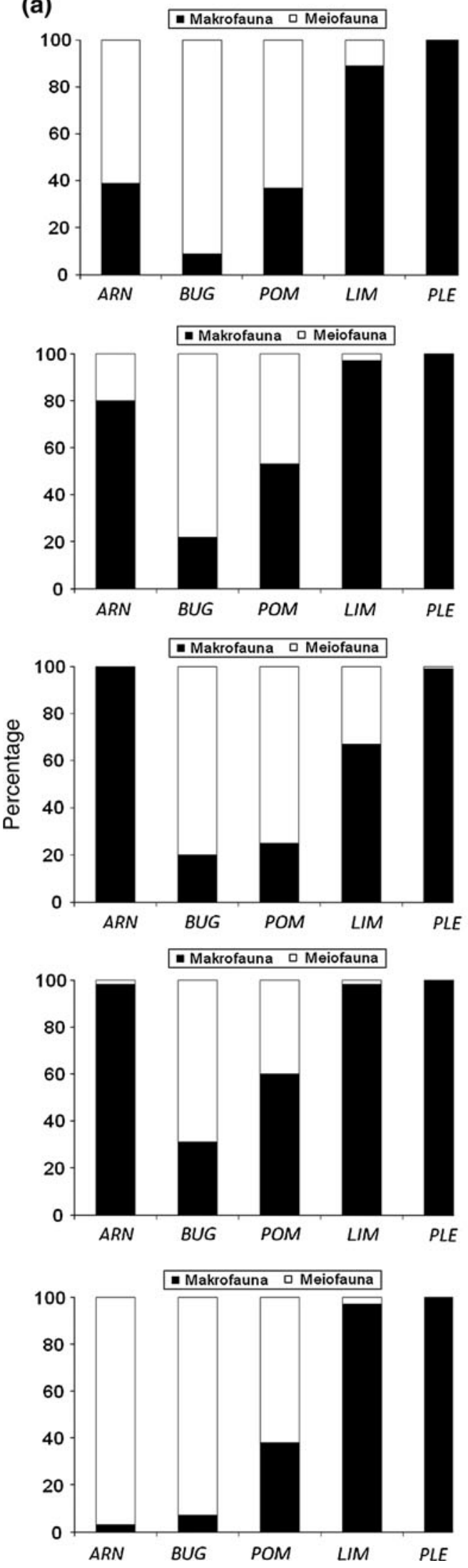

(b)
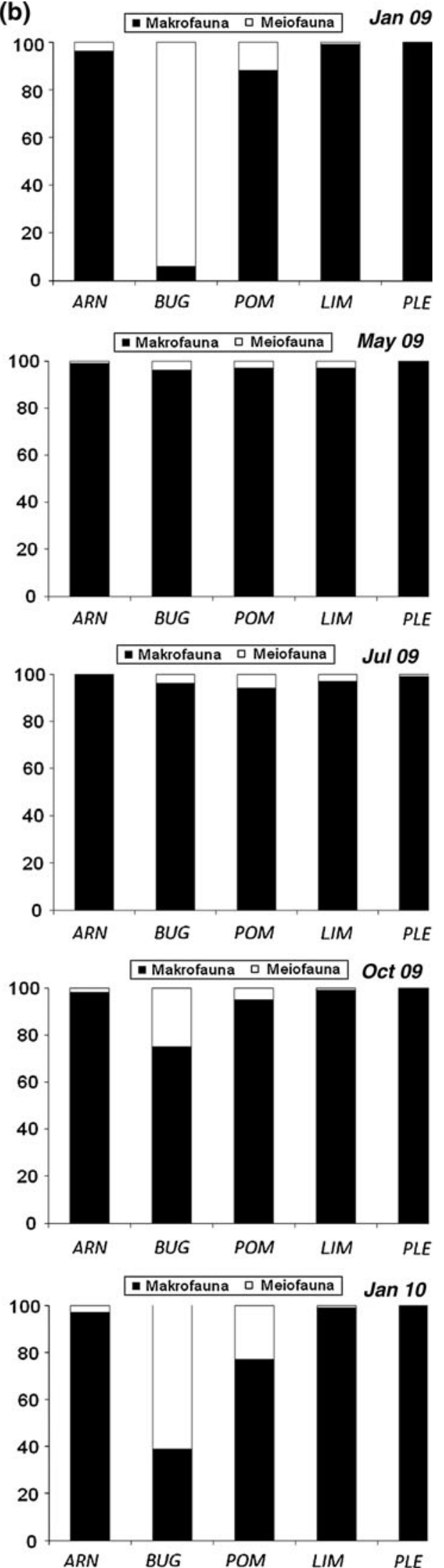
Table 3 Relative importance $R_{\mathrm{I}}(\%)$ of harpacticoid copepod species found in the sediment cores $\left(8.80 \mathrm{~cm}^{2}\right)$ per season and their seasonal contribution $(\%)$ to the harpacticoid assemblage indicated by SIMPER analysis (based on non-transformed abundance data)

\begin{tabular}{|c|c|c|c|c|c|c|c|c|}
\hline \multirow[t]{2}{*}{ Species } & \multicolumn{2}{|l|}{ May 09} & \multicolumn{2}{|l|}{ Jul 09} & \multicolumn{2}{|l|}{ Oct 09} & \multicolumn{2}{|l|}{ Jan 10} \\
\hline & $R_{\mathrm{I}}(\%)$ & Contrib (\%) & $R_{\mathrm{I}}(\%)$ & Contrib $(\%)$ & $R_{\mathrm{I}}(\%)$ & Contrib (\%) & $R_{\mathrm{I}}(\%)$ & Contrib $(\%)$ \\
\hline \multicolumn{9}{|l|}{ Ectinosomatidae } \\
\hline H. canaliculatum & 20.7 & 30.7 & 14.2 & 10.7 & 26.9 & 26.8 & 15.5 & 12.8 \\
\hline P. minor & 16.4 & 35.1 & 9.9 & 19.7 & 11.9 & 31.7 & 17.5 & 32.2 \\
\hline Ectinosoma spp. & 12.2 & 6.3 & $<0.1$ & $<0.1$ & $<0.1$ & $<0.1$ & 1.5 & $<0.1$ \\
\hline \multicolumn{9}{|l|}{ Longipediidae } \\
\hline L. coronata & 14.9 & 2.1 & 34.5 & 15.3 & 12.6 & 1.1 & 1.9 & $<0.1$ \\
\hline \multicolumn{9}{|l|}{ Ameiridae } \\
\hline P. crassicornis & 8.1 & 14.5 & 5.1 & 10.7 & 3.8 & $<0.1$ & 7.8 & 13.4 \\
\hline Psyllocamptus spp. & $<0.1$ & $<0.1$ & 0.8 & $<0.1$ & $<0.1$ & $<0.1$ & $<0.1$ & $<0.1$ \\
\hline \multicolumn{9}{|l|}{ Idyanthidae } \\
\hline T. reducta & 7.4 & 8.0 & 6.4 & 15.8 & 2.1 & 5.6 & 10.3 & 20.4 \\
\hline T. minuta & $<0.1$ & $<0.1$ & $<0.1$ & $<0.1$ & 2.1 & $<0.1$ & $<0.1$ & $<0.1$ \\
\hline \multicolumn{9}{|l|}{ Miraciidae } \\
\hline B. aemula & 4.46 & $<0.1$ & 4.2 & $<0.1$ & 12.9 & 26.5 & 5.5 & $<0.1$ \\
\hline D. reflexa & 1.09 & $<0.1$ & - & - & - & - & - & - \\
\hline \multicolumn{9}{|l|}{ Cletodidae } \\
\hline C. limicola & 1.6 & $<0.1$ & 0.5 & $<0.1$ & - & - & 4.9 & 4.4 \\
\hline C. tenuipes & - & - & 0.4 & $<0.1$ & - & - & 4.9 & $<0.1$ \\
\hline Stylicletodes spp. & - & - & 0.9 & $<0.1$ & - & - & - & - \\
\hline E. propinquum & 1.81 & $<0.1$ & 5.3 & 10.3 & 4.4 & 2.1 & 8.4 & 7.4 \\
\hline E. gariene & - & - & - & - & 1.4 & $<0.1$ & - & - \\
\hline E. longifurcatum & - & - & - & - & 3.1 & 1.1 & 9.8 & 6.2 \\
\hline \multicolumn{9}{|l|}{ Canuellidae } \\
\hline Canuella spp. & 3.28 & $<0.1$ & - & - & - & - & - & - \\
\hline \multicolumn{9}{|l|}{ Tachidiidae } \\
\hline Microarthridion spp. & 0.75 & $<0.1$ & - & - & - & - & - & - \\
\hline \multicolumn{9}{|l|}{ Rhizothricidae } \\
\hline R. curvatum & - & - & - & - & 4.0 & $<0.1$ & - & - \\
\hline Siphonostomatoida & 1.02 & $<0.1$ & - & - & - & - & - & - \\
\hline Harpacticoids copepodites & - & - & 8.3 & 14.8 & 2.5 & $<0.1$ & 2.5 & $<0.1$ \\
\hline Harpacticoids unident & 6.2 & 2.1 & 9.3 & 3.7 & 12.4 & 5.9 & 9.5 & 3.2 \\
\hline
\end{tabular}

Important values are marked in bold

season (Table 3). One exception was found in May with juvenile bivalves as the most frequently occurring prey group $\left(I_{\mathrm{O}}=74 \%\right)$, even though its biomass was low $\left(I_{\mathrm{W}}=<1 \%\right)$.

For $P$. minutus, meiofaunal prey was most important in January (2009 and 2010) and July comprising the diet by more than $60 \%$ in terms of occurrence as well as abundance (Fig. 2). Although the diversity of meiofaunal prey per season was generally higher in the diet of $P$. minutus compared to B. luteum, harpacticoids were both the most frequently occurring and the most abundant prey group, also exhibiting the highest biomass (Table 3). According to the three indices, the second most important prey group in most months (May, July and January) were nematodes. Juvenile bivalves became an important prey group numerically, as well as in terms of occurrence, in May $\left(I_{\mathrm{N}}=21 \% ; I_{\mathrm{O}}=45 \%\right.$, respectively), similar to the diet of B. luteum. Ostracods were found regularly in the stomach contents in all seasons, but only in low numbers.

Clear seasonal differences in both the frequency of occurrence and abundance of meiofaunal prey were found in the diet of A. laterna and L. limanda (Fig. 2). Meiofauna dominated the diet of A. laterna in January and May, whereas the diet of $L$. limanda was mainly comprised of meiofauna in July. Among the meiofaunal prey groups, 
harpacticoids dominated the diets of both fish species in each season according to the frequency of occurrence, abundance and biomass (Table 3). Juvenile bivalves became relevant in abundance for A. laterna in May $\left(I_{\mathrm{N}}=28 \%\right)$ and in terms of occurrence for L. limanda in May and July $\left(I_{\mathrm{O}}=9\right.$ and $7 \%$, respectively). Ostracods were remarkably frequent in the diet of L. limanda in May $\left(I_{\mathrm{O}}=20 \%\right)$, being the second most important prey group in this month.

Pleuronectes platessa did not utilize meiofauna prey during the entire study period (Fig. 2). Therefore, P. platessa was excluded from subsequent analyses.

Selectivity in foraging

\section{Harpacticoid copepods}

In total, 19 different harpacticoid species belonging to 9 families were found in the study area. The most important family in the harpacticoid community was Ectinosomatidae, almost all belonging to the two species $H$. canaliculatum (Por 1964) and P. minor (Scott T. and A. 1894) (Table 4). Other important species that mainly contributed to the harpacticoid assemblage were Pseudameira crassicornis Sars, G.O. 1911 (Ameiridae), Tachidiella reducta Sars, G.O. 1909 (Idyanthidae) and L. coronata Claus, 1863 (Longipediidae).

Seasonally, the harpacticoid community structure differed significantly between May and July (ANOSIM, $R=0.52, p=0.0001$ ) and July and October (ANOSIM, $R=0.60, p=0.0001$ ) (Table 5). P. minor and $H$. $c a$ naliculatum, even though both are characteristic species in the harpacticoid community in all seasons, contributed differently in different seasons with more than $35 \%$ from October to May, but decreasing in July to $28 \%$. A similar seasonal pattern for these two harpacticoid species was found using the importance index $\left(R_{\mathrm{I}}\right)$, which combines beside percentage of abundance also frequency of occurrence and biomass (Table 4). In contrast, an opposite trend with the highest abundances as well as importance values in summer and lowest in winter was found for $L$. coronata and copepodites. Particularly in summer, the harpacticoid community was mainly characterized by $L$. coronata as the most important species $\left(R_{\mathrm{I}}=35 \%\right)$.

Beatricella aemula (Scott T. 1893) was most important in the harpacticoid community in October, whereas Cletodes limicola Brady 1872 and Enhydrosoma longifurcatum Sars, G.O. 1909 were most important in the harpacticoid community in winter. No general seasonal trends according to the $R_{\mathrm{I}}$ index were found for P. crassicornis, T. reducta and Enhydrosoma propinquum (Brady and Robertson in Brady 1880).
Table 4 One-way analysis (ANOSIM) between harpacticoid copepod communities in the sediment cores $\left(8.80 \mathrm{~cm}^{2}\right)$ per season based on non-transformed abundance data

\begin{tabular}{lll}
\hline Groups/test & $R$ statistic & $\begin{array}{l}\text { Significance } \\
\text { level }\end{array}$ \\
\hline $\begin{array}{l}\text { Sediment cores } \\
\text { Global test }\end{array}$ & \\
All seasons (Jan, May, Jul, Oct) & 0.35 & 0.001 \\
Pairwise test & & \\
Jan, May & 0.24 & 0.005 \\
Jan, Jul & 0.28 & 0.001 \\
Jan, Oct & 0.43 & 0.002 \\
May, Jul & $\mathbf{0 . 5 7}$ & 0.001 \\
May, Oct & 0.30 & 0.001 \\
Jul, Oct & $\mathbf{0 . 5 8}$ & 0.001 \\
\hline
\end{tabular}

Bold values are significant

\section{Prey selection of harpacticoid copepods}

In total, eight different harpacticoid species belonging to six families were found in the stomach contents. The most important families in the diet of all the four fish species were Ectinosomatidae, belonging almost entirely to the species Pseudobradya spp. and $H$. canaliculatum, and Longipediidae, belonging exclusively to Longipedia spp. (Table 6). Families such as Ameiridae, Idyanthidae and Miraciidae were generally of low importance in the fish diets, although they occurred in the sediment cores.

Significant differences in the abundance of harpacticoid species were found in all studied fish diets (Table 7). For $B$. luteum, the harpacticoid community in the winter diet 2009 differed significantly from that in all other seasons (Table 7). This was attributed to Pseudobradya spp., the most abundant prey species in January $2009\left(R_{\mathrm{I}}=98 \%\right)$, and Longipedia spp., the most abundant prey species between May and October $\left(R_{\mathrm{I}}>90 \%\right.$, respectively). A high positive selection was found for Pseudobradya spp. in January 2010 and Longipedia spp. between May and October (Table 6). High $E$ values of $H$. $c a$ naliculatum as well as $T$. reducta in January only indicated a strong selection for these two species during winter.

A similar seasonal trend of diet differences in harpacticoids was found in the stomachs of $P$. minutus, even though less distinct compared to B. luteum (Tables 6, 7). Pseudobradya spp. was the most important harpacticoid in the diet of both winters $\left(R_{\mathrm{I}}=47 \%\right.$ and $\left.54 \%\right)$ and was replaced by Longipedia spp. between spring $\left(R_{\mathrm{I}}=97 \%\right)$ and autumn $\left(R_{\mathrm{I}}=57 \%\right)$. Highly positive values of Ivlev's index for Pseudobradya spp. in autumn and winter and for Longipedia spp. during summer indicated prey selection, whereas the negative $E$ values of Pseudobradya spp. in spring and summer indicated avoidance. Apart from E. propinquum in winter, cletodid species were always selected against. 
Table 5 Percentage of frequency occurrence $\left(I_{\mathrm{O}}\right)$, numerical abundance $\left(I_{\mathrm{N}}\right)$ and biomass $\left(I_{\mathrm{W}}\right)$ of meiofauna prey groups found in the diet of the studied fish species per season

\begin{tabular}{|c|c|c|c|c|c|c|c|c|c|c|c|c|c|c|c|}
\hline \multirow[t]{2}{*}{ Prey groups } & \multicolumn{3}{|l|}{ Jan 09} & \multicolumn{3}{|l|}{ May 09} & \multicolumn{3}{|l|}{ Jul 09} & \multicolumn{3}{|l|}{ Oct 09} & \multicolumn{3}{|l|}{ Jan 10} \\
\hline & $I_{\mathrm{O}}(\%)$ & $I_{\mathrm{N}}(\%)$ & $I_{\mathrm{W}}(\%)$ & $I_{\mathrm{O}}(\%)$ & $I_{\mathrm{N}}(\%)$ & $I_{\mathrm{W}}(\%)$ & $I_{\mathrm{O}}(\%)$ & $I_{\mathrm{N}}(\%)$ & $I_{\mathrm{W}}(\%)$ & $I_{\mathrm{O}}(\%)$ & $I_{\mathrm{N}}(\%)$ & $I_{\mathrm{O}}(\%)$ & $I_{\mathrm{N}}(\%)$ & $I_{\mathrm{W}}(\%)$ & $I_{\mathrm{W}}(\%)$ \\
\hline \multicolumn{16}{|l|}{ B. luteum } \\
\hline Harpacticoids & 66.6 & 96.5 & 99.9 & 26.4 & 76.1 & 99.9 & 89.8 & 99.7 & 99.9 & 98.9 & 99.8 & 99.9 & 92.6 & 99.3 & 99.9 \\
\hline Bivalves & 33.4 & 3.5 & 0.1 & 73.6 & 23.9 & 0.1 & 10.2 & 0.3 & 0.1 & 1.1 & 0.2 & 0.1 & 7.4 & 0.3 & 0.1 \\
\hline $\begin{array}{r}\text { Number of } \\
\text { stomachs }\end{array}$ & 350 & & & 296 & & & 295 & & & 273 & & & 215 & & \\
\hline \multicolumn{16}{|l|}{$P$. minutus } \\
\hline Harpacticoids & 78.9 & 72.2 & 97.0 & 60.8 & 20.1 & 98.2 & 81.7 & 58.9 & 99.0 & 92.0 & 98.1 & 97.1 & 72.9 & 78.2 & 97.1 \\
\hline Bivalves & - & - & - & 45.4 & 21.2 & 0.2 & - & - & - & 3.2 & 1.5 & 0.3 & - & - & - \\
\hline Ostracods & 1.3 & 0.6 & 0.5 & 9.1 & 8.2 & 0.4 & 3.9 & 0.6 & 0.3 & 3.2 & 0.4 & 3.4 & 2.1 & 0.4 & 0.2 \\
\hline Nematodes & 21 & 27.4 & 2.8 & 27.3 & 72.8 & 1.8 & 11.5 & 40.5 & 1.1 & - & - & - & 16.7 & 21.2 & 2.8 \\
\hline $\begin{array}{r}\text { Number of } \\
\text { stomachs }\end{array}$ & 136 & & & 120 & & & 26 & & & 294 & & & 65 & & \\
\hline \multicolumn{16}{|l|}{ A. laterna } \\
\hline Harpacticoids & 93.7 & 88.3 & 99.8 & 92.9 & 72.0 & 99.9 & - & - & - & 100 & 100 & 100 & 100 & 100 & 100 \\
\hline Bivalves & 6.3 & 11.7 & 0.2 & 7.1 & 28.0 & 0.1 & - & - & - & - & - & - & - & - & - \\
\hline $\begin{array}{r}\text { Number of } \\
\text { stomachs }\end{array}$ & 158 & & & 28 & & & 71 & & & 169 & & & 66 & & \\
\hline \multicolumn{16}{|l|}{ L. limanda } \\
\hline Harpacticoids & 94.2 & 96.4 & 99.8 & 79.5 & 90.9 & 99.7 & 90.3 & 98.5 & 99.8 & 97.7 & 99.4 & 99.9 & 92.6 & 95.5 & 99.9 \\
\hline Bivalves & 5.8 & 3.6 & 0.2 & 9.3 & 1.1 & 0.2 & 7.2 & 1.5 & 0.2 & 2.3 & 0.6 & 0.1 & 7.4 & 4.5 & 0.1 \\
\hline Ostracods & - & - & - & 20.0 & 9.1 & 0.1 & - & - & - & - & - & - & - & - & - \\
\hline $\begin{array}{r}\text { Number of } \\
\text { stomachs }\end{array}$ & 111 & & & 50 & & & 226 & & & 122 & & & 69 & & \\
\hline
\end{tabular}

Important values are marked in bold

Only two harpacticoid species, namely Pseudobradya spp. and Longipedia spp., comprised the diet of A. laterna as well as of $L$. limanda during the study period (Table 6). There were significant seasonal differences in the diets in both fish species (Table 7). According to $R_{\mathrm{I}}$ values, Pseudobradya spp. was of greatest importance in the diet of A. laterna in January and May 2009, whereas Longipedia spp. was most important from October to January 2010 (Table 6). In the diet of L. limanda, both harpacticoids were found with highest $R_{\mathrm{I}}$ values for Pseudobradya spp. in January (2009 and 2010) and for Longipedia spp. in May and July. This contrasting prey selection between A. laterna and L. limanda on both harpacticoids was also shown by Ivlev's selection index, being positive for Pseudobradya spp. in spring (A. laterna) and winter (L. limanda), whereas positive values for Longipedia spp. were found in summer (L. limanda) and autumn (A. laterna, L. limanda).

Size aspects

A decreasing frequency of occurrence of harpacticoid prey with increasing fish length $L_{\mathrm{T}}$ was found in the diet of all studied fish species (Fig. 3). A similar trend in harpacticoid abundances was found for B. luteum, A. laterna and L. limanda, whereas the numerical utilization of harpacticoids by $P$. minutus was largely independent of fish size $(4-7 \mathrm{~cm}$ $\left.L_{\mathrm{T}}\right)\left(I_{\mathrm{N}}=20 \%\right)$. Highest abundances of harpacticoids were found in the diet of $B$. luteum below $9 \mathrm{~cm} L_{\mathrm{T}}$, in the diet of $P$. minutus and A. laterna between $3 \mathrm{~cm}$ and $4 \mathrm{~cm}$ $L_{\mathrm{T}}$ and in the diet of $L$. limanda of $L_{\mathrm{T}}=7 \mathrm{~cm}$.

On the basis of these results, it should be noted that no individuals of $P$. platessa below $10 \mathrm{~cm} L_{\mathrm{T}}$ were caught in the present study. However, meiofauna was previously found to be an important prey in small-sized plaice between fish lengths of 4 and $10 \mathrm{~cm} L_{\mathrm{T}}$ (Gee 1989).

\section{Discussion}

Numerically, meiofaunal prey dominated the diet of B. luteum and $P$. minutus in all seasons, was found seasonally in the diet of A. laterna and L. limanda and was absent in the diet of $P$. platessa between 10 and $20 \mathrm{~cm}$ body size. Thus, although sharing the same habitat, seasonal differences in meiofauna prey resources do exist between these small-sized demersal fish species. In terms of prey biomass, macrofaunal prey dominated in all fish diets reflecting the 


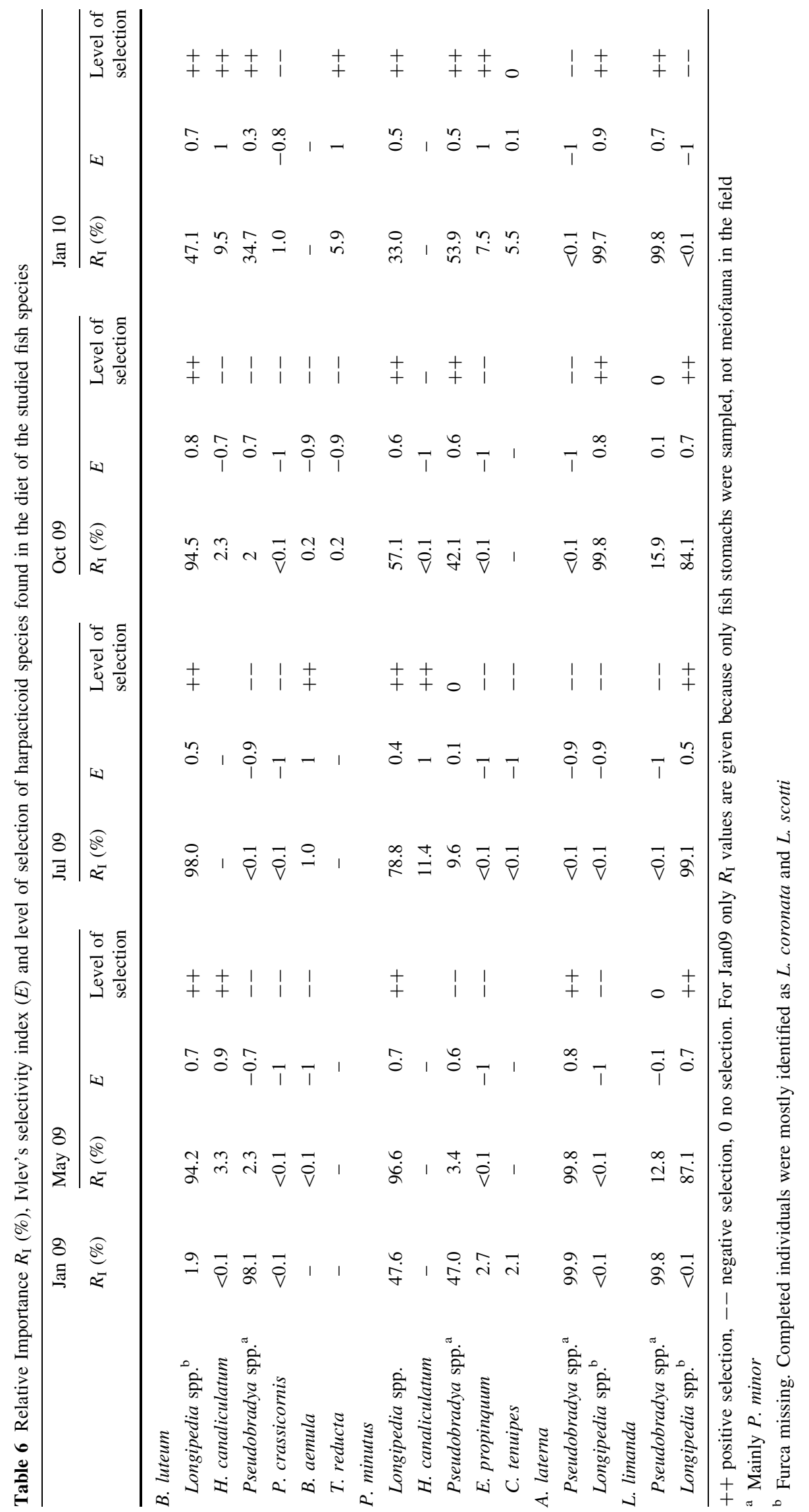


Table 7 One-way analysis (ANOSIM) of harpacticoid copepod composition in the fish diets (based on non-transformed abundance data)

\begin{tabular}{|c|c|c|c|c|c|c|c|c|}
\hline \multirow{2}{*}{$\begin{array}{l}\text { Groups/test } \\
\text { Stomach contents }\end{array}$} & \multicolumn{4}{|c|}{$R$ statistic } & \multicolumn{4}{|c|}{ Significance level } \\
\hline & BUG & & POM & & ARN & & LIM & \\
\hline \multicolumn{9}{|l|}{ Global test } \\
\hline All seasons (Jan 09, May, Jul, Oct, Jan 10) & 0.83 & 0.001 & 0.31 & 0.001 & 0.34 & 0.016 & 0.58 & 0.007 \\
\hline \multicolumn{9}{|l|}{ Pairwise test } \\
\hline Jan 09, May & 1 & 0.001 & 0.45 & 0.002 & 0.38 & 0.210 & 1 & 0.330 \\
\hline Jan 09, Jul & 1 & 0.001 & 0.54 & 0.008 & 1 & 0.001 & 1 & 0.018 \\
\hline Jan 09, Oct & 0.99 & 0.001 & 0.07 & 0.175 & 0.40 & 0.430 & 1 & 0.330 \\
\hline Jan 09, Jan 10 & 0.39 & 0.001 & 0.12 & 0.075 & 0.38 & 0.210 & 0.45 & 0.330 \\
\hline May, Jul & 0.81 & 0.001 & 0.19 & 0.088 & 1 & 0.001 & 0.13 & 0.320 \\
\hline May, Oct & 0.42 & 0.004 & 0.27 & 0.003 & 0.21 & 0.330 & 0.1 & 0.500 \\
\hline May, Jan 10 & 0.48 & 0.005 & 0.61 & 0.001 & 0.50 & 0.005 & 0.13 & 0.330 \\
\hline Jul, Oct & 0.39 & 0.004 & 0.21 & 0.071 & 1 & 0.001 & 0.48 & 0.050 \\
\hline Jul, Jan 10 & 1 & 0.001 & 0.71 & 0.005 & 1 & 0.001 & 0.60 & 0.050 \\
\hline Oct, Jan 10 & 0.94 & 0.001 & 0.30 & 0.007 & 0.01 & 0.005 & 0.25 & 0.500 \\
\hline
\end{tabular}

Species codes of the studied fish species are explained in Table 1

Bold values are significant

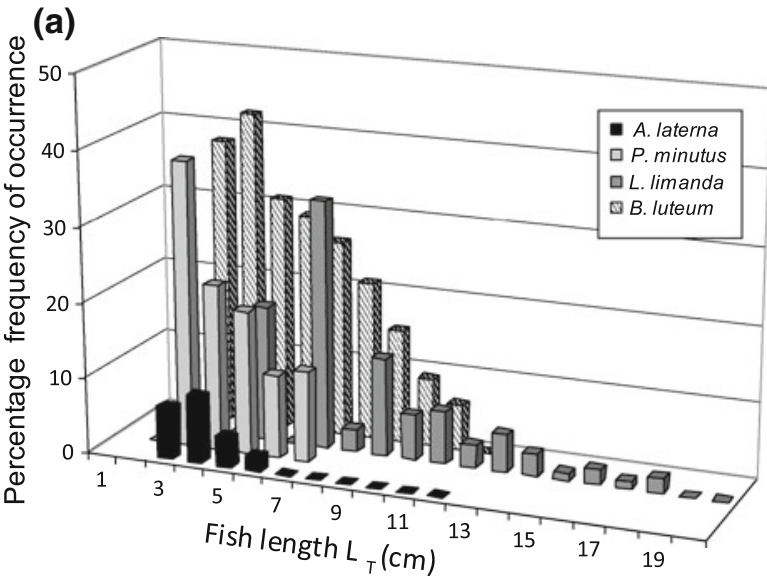

(b)

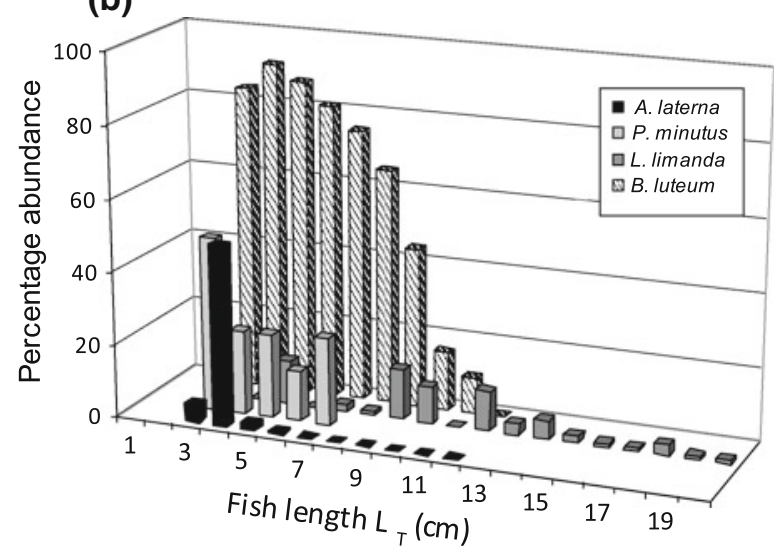

Fig. 3 Percentage of $\mathbf{a}$ frequency of occurrence and $\mathbf{b}$ abundance of harpacticoid prey per fish length $L_{\mathrm{T}}$ of the studied fish species higher weight of macrofaunal compared to meiofaunal prey. For details on fish predation on macrofaunal prey groups, see Schückel et al. (2011) and Schückel et al. (2012).

Among different meiofaunal prey groups, harpacticoids were always of primary importance in the diet of each of the studied fish species during all seasons, whereas nematodes dominated the meiofauna community in the study area.

The meiofauna community in the study area

Nematodes were always the dominant meiofauna group in sediment samples in terms of abundance, while harpacticoids occurred most frequently. Seasonal differences were negligible for meiofaunal abundance but significant for biomass, due to a marked increase in harpacticoids in summer.

Previous research on meiofauna communities in the North Sea has also shown that nematodes are the dominant meiofauna group in terms of abundance accounting for at least $90 \%$ of the total meiofauna (Juario 1975; Heip and Craeymeersch 1995). Their densities ranged from 61 to 4,167 ind. $/ 10 \mathrm{~cm}^{2}$ and they were especially abundant in the southern North Sea (Huys et al. 1992). Harpacticoids ranked second in abundance, whereas other groups such as polychaetes, kinorhynchs, gastrotrichs, bivalves and ostracods were far less abundant (Juario 1975; Govaere et al. 1980; Heip et al. 1992; Heip and Craeymeersch 1995). Seasonally, meiofauna abundance generally peaks in spring and summer following an increase in food supply after the spring phytoplankton bloom, whereas abundance is low during autumn and winter, when most meiofauna groups 
live deeper in the sediment (Olafsson and Elmgren 1997). Only harpacticoids are known to occur most of the year, concentrated in the upper six centimetre of the sediment (Huys et al. 1986). However, in the area of investigation in the German Bight ("Box A"), seasonal changes of both abundance and occurrence of meiofauna groups were small. Only an increase in copepodite occurrence as well as of harpacticoid biomass was found during summer, probably triggered by reproductive activities of harpacticoid copepods and sufficient food supply due to phytoplankton sedimentation after the spring bloom (Rudnick et al. 1985).

Confirming previous results of the North Sea Benthos Survey (for details see Huys et al. 1992), epibenthic species belonging to the family Ectinosomatidae (mainly $\mathrm{H}$. $\mathrm{ca}$ naliculatum and $P$. minor) and Longipediidae (mainly L. coronata) dominated the harpacticoid community structure in the study area. The pelophilic species $P$. crassicornis (Ameiridae) as well as $T$. reducta (Idyanthidae) were also important in this community. In contrast, interstitial species were completely absent in the present study, although interstitial species belonging to the family Leptastacidae (mainly Leptastacus and Paraleptastacus) were described as characteristic species in previous studies (Heip et al. 1992). Leptastacus and Paraleptastacus are both known as interstitial sliders (Huys et al. 1992), probably able to penetrate deeper into the sediment than the first five centimetre, which were sampled here.

Seasonally, abundances of Ectinosomatidae and Longipediidae differed significantly, being highest for $P$. minor and $H$. canaliculatum between October and May but lowest in July, whereas the reverse with a peak in abundance in July was found for L. coronata.

Such seasonal changes of harpacticoid densities are mostly observed in vertical distribution patterns, which are caused by migrations in response to seasonal fluctuations in environmental parameters (e.g. oxygen, salinity) and physiological adaption such as changes in growth rate and fecundity in response to environmental pressures. More details in terms of species-specific migration patterns in harpacticoids will be given in the section below directly related to its function as potential prey source for the studied demersal fish.

\section{Meiofauna as prey source of demersal fish}

Diets of $B$. luteum and $P$. minutus were numerically dominated by harpacticoids during all seasons. Such a dominance of harpacticoid prey throughout the seasons has also been reported for B. luteum in the Western Mediterranean (Tito de Morais and Bodiou 1984) and the Scottish coast (Nottage and Perkins 1983) and for several gobiid species in the North Sea (Zander 1979), in the Adriatic Sea (Kovačić 2001, 2007; Kovačić and la Mesa 2008) and in the Gulf of Mexico (Fitzhugh and Fleeger 1985). Other meiofaunal prey groups (juvenile bivalves, ostracods and nematodes) became important in their diets only in May, indicating a seasonal change in prey preferences during spring. Constrained by their small mouth gapes and a more sediment surface-orientated feeding strategy, B. luteum and gobiids catch very small benthic prey buried in the top few centimetres of the sediment or living very close to the sediment surface, which represents the habitat of most harpacticoids (Tito de Morais and Bodiou 1984; Darnaude et al. 2001). Furthermore, their caloric values are $35 \%$ higher than those of most other meiofaunal groups (Gee 1989). Consequently, the relatively low costs of capturing harpacticoids and their relatively high caloric content turn them into a more energy-efficient prey. However, the seasonal trend to meet energy requirements in spring also by eating other meiofauna prey groups (e.g. bivalves) as well as macrofauna was also confirmed for $P$. minutus in the Baltic Sea, even though harpacticoids always comprised the most important prey group in each season (Aarnio and Bonsdorff 1993).

Meiofauna was more important as a seasonal prey source in the diet of A. laterna and small-sized L. limanda. Meiofauna mainly characterized the diet of A. laterna during winter, dominated by harpacticoids in terms of occurrence as well as abundance. In contrast, harpacticoids dominated the diet of L. limanda spring and summer. Similar to both fish species discussed before, juvenile bivalves became an important prey group in spring. On the basis of their mouth morphology, it can be assumed that A. laterna and L. limanda are able to feed on larger and hence more energetically valuable prey (Piet et al. 1998; Schückel et al. 2011, 2012). Consequently, mainly macrofaunal prey (e.g. crustaceans and polychaetes) comprised the diets of both fish species, whereas meiofaunal prey seems to be of less diet importance. Confirming this, preferential feeding on macrofauna was also found in previous diet studies for both fish species (e.g. Gibson and Ezzi 1980; Bayan et al. 2008; Schückel et al. 2011) and furthermore, was already found in relatively small fish ( $L_{\mathrm{T}}$ 's $<10 \mathrm{~cm}$; Schückel et al. 2012).

However, a reduced feeding activity of A. laterna in winter resulting in low stomach functions and low mobility, together with a reduced availability of larger benthic prey in the field, may have caused the observed increasing numbers of harpacticoids in the January stomachs. Assuming for dab a rather weak condition in spring after the winter feeding pause and the spawning period (Knust 1986; Hinz et al. 2005), harpacticoids may also provide an easily available and nutritious prey to fulfil energy requirements.

Increasing abundances of juvenile bivalves in all fish diets in May indicated a match with spawning periods of bivalves in this area (Beukema et al. 1998; Reiss and 
Kröncke 2004). The subsequent decrease of juvenile bivalves in occurrence, abundance and biomass in the field during summer might be due to predation pressure of the studied fish species. Similar results of a strong predation pressure on juvenile bivalves after spawning was also found for small plaice in the Baltic Sea (Olafsson and Elmgren 1997) and for gobiids in the Adriatic Sea (Kovačić and la Mesa 2008). Thus, seasonal changes of meiofauna in the diet composition of small demersal fish could be the result of seasonal availability of suitable meiofaunal prey (see Tables 2, 3).

Although nematodes represented, depending on season, between 93 and $98 \%$ of the total number of individuals in the sediment, they were completely absent in the flatfish diets but, interestingly, they occurred in almost each season in the diet of P. minutus (see Table 5). This agrees well with the literature showing that harpacticoids are usually the most abundant prey group in the fish diets, whereas nematodes dominate the sediment (e.g. Gee 1989 and references therein). Food selection of demersal fish depends on the availability of the prey, which is mainly determined by its density, visibility, accessibility and mobility (Nelson and Coull 1989). Feeding of the studied fish on meiofauna was mainly focused on harpacticoids living on or near the sediment surface, whereas nematodes have a deeper vertical distribution (Aarnio and Bonsdorff 1993; Aarnio 2000). Another factor that may explain the absence of nematodes in the stomachs could be differences in digestion rates for these two taxa. Harpacticoids have an exoskeleton that is slowly digested and remains in the gut for several hours after ingestion, while nematodes are softbodied and are digested rapidly (Alheit and Scheibel 1982; Scholz et al. 1991), thus probably giving a false impression of diet composition. A third explanation implies that physical disturbance caused by searching fish in the sediment may have suspended nematodes from the uppermost sediment layer or swept them away (Fitzhugh and Fleeger 1985; Gee 1989). This last explanation, regarding our study, also indicates best why, on the one hand, nematodes are absent in the flatfish diets, but on the other hand, are a dominant prey item in the goby diet. Similar findings of nematodes in gobiid stomachs were also reported for $P$. minutus and P. lozanoi in the North Sea (Fonds 1973) as well as for two closely related gobiids in the Gulf of Mexico (Fitzhugh and Fleeger 1985). The latter assumed that gobies graze sediments more or less indiscriminately in addition to sight feeding for larger prey. This rather passive feeding strategy in searching prey may contradict with a more active visual feeding strategy of flatfish remaining motionless on the bottom at first, and then periodically lunging rapidly forward, causing the upper sediment layers to float in suspension (de Groot 1971; Hoghue and Carey 1982). Also morphological differences (e.g. body shape, mouth gape) between gobiids and pleuronectids may enable $P$. minutus to penetrate in deeper sediments.

Prey selectivity

Fish predation on harpacticoids was highly selective for the two species Pseudobradya spp. and Longipedia spp. Pseudobradya spp. was found almost exclusively in fish stomachs in winter, whereas Longipedia spp. dominated the stomach contents between spring and autumn.

Selective feeding on harpacticoid species seems to be common in many fish species. For instance, Alheit and Scheibel (1982) showed exclusive feeding on L. helgolandica by predatory fishes in a Bermudan lagoon. Hicks (1984), in his study of flatfish feeding on intertidal sandflats in New Zealand, also found exclusive feeding on one harpacticoid species (P. megarostrum). For B. luteum from the Mediterranean, a marked preference for Pseudobradya beduina was described, whereas the goby D. quadrimaculatus from the same habitat fed exclusively on $\mathrm{H}$. $\mathrm{ca}$ naliculatum (Tito de Morais and Bodiou 1984).

Firstly, by comparing the meiofauna community in the sediment with that in the fish stomachs, it becomes clear that the studied fish species fed almost exclusively on the most abundant harpacticoids in the sediment. Thus, fish predation on Pseudobradya spp. in winter and Longipedia spp. in summer may merely reflect their high prey densities in the field. Contradictory to this, Ivlev's high selection values for all studied fish species on both harpacticoids clearly suggested a positive prey selection.

Secondly, harpacticoids differ in vertical distribution within the sediment. By dwelling in the uppermost sediment layers, Pseudobradya spp. and Longipedia spp. are more vulnerable to predation compared to deeper interstitial or burrowing species (Gee 1987). Consequently, interstitial species, such as $B$. aemula (also known to build a tube into which it retreats when disturbed; Huys et al. 1986) and E. propinquum, were negatively selected. Only the upward migration in the sediment of $B$. aemula during summer leads to an increase in fish predation (Huys et al. 1986), explaining the positive prey selection for this harpacticoid in the diet of B. luteum only in July.

Moreover, Pseudobradya spp. and Longipedia spp. are both emergers, swimming into the overlying water (typically during the night) and returning to the seabed during the day (Sedlacek and Thistle 2006). Thus, Pseudobradya is classified as a moving water emerger during all seasons, whereas Longipedia moves in the water column mainly in summer (Thistle 2003), leading to a greater susceptibility of Longipedia sp. for visual predators during summer. Diets of the studied fish species changed towards an intensively feeding on Longipedia spp. in July, even though Pseudobrayda spp. also occurred in high abundances in the 
sediment. In this context, prey selection on Longipedia spp. could also be prey size dependent. Longipedia spp. is significantly larger (mean length, $0.9 \mathrm{~mm}$; own data), compared to Pseudobradya spp. (mean length, $0.4 \mathrm{~mm}$; own unpubl. data), and consequently more favourable as a source of energy compared to Pseudobrayda spp. Such a prey size selection was also found by McCall (1992) for juvenile flounder, mainly feeding on the largest available harpacticoids.

\section{Size aspects}

The relative contribution of meiofauna and macrofauna to the diet composition of fish depends mostly on predator size (e.g. Gee 1989; Kovačić and la Mesa 2008; Schückel et al. 2012). On the basis of the optimal foraging theory, smaller fish eat smaller prey and switch usually to larger prey to maximize their net energy gain as fish length increases (Schoener 1971). Confirming this, harpacticoids as the prevalent meiofaunal prey rapidly decreased in terms of frequency of occurrence as well as numerical abundance in the diets of all studied fish species with increasing fish size. Interestingly, threshold lengths at which the importance of harpacticoid prey decreased differed for the studied species. The abundance of harpacticoid prey decreased already at relatively small individual size in A. laterna and P. minutus $\left(3-4 \mathrm{~cm} L_{\mathrm{T}}\right)$, whereas they were still abundant prey for $B$. luteum also at larger fish sizes $\left(8 \mathrm{~cm} L_{\mathrm{T}}\right)$. Similar results were described for gobies B. affinis in the Adriatic Sea (Kovačić and la Mesa 2008) and for P. minutus in the Baltic Sea (Aarnio and Bonsdorff 1993), indicating significant differences between the diet of large- and small-sized individuals, switching from meiofaunal to macrofaunal prey at approximately $3-4 \mathrm{~cm} L_{\mathrm{T}}$, respectively. Harpacticoids in the diet of the goby D. quadrimaculatus, still constituting $50 \%$ in the total diet at $3 \mathrm{~cm}$ fish length, decrease to almost $0 \%$ in individuals up to a fish length of $5 \mathrm{~cm}$ (Tito de Morais and Bodiou 1984). Predominant feeding on harpacticoids was also found in A. laterna as well as for the closely related A. thorni with $L_{\mathrm{T}}$ 's between 5 and $6 \mathrm{~cm}$, but changing rapidly towards polychaetes and fish prey at larger size (Bayan et al. 2008). In contrast, for a B. luteum population on the Scottish coast, harpacticoids were still an important prey in the diets of individuals reaching fish lengths of $8 \mathrm{~cm} L_{\mathrm{T}}$ (Nottage and Perkins 1983). Mainly morphological constraints (e.g. mouth gape, jaw structures) determine the threshold length for fish below which meiofauna are of no value as prey. In most flatfish species and gobiids, this threshold length is about $3 \mathrm{~cm}$ (total fish length). Above this size, macrofauna are always the dominant prey, whereas below this size, harpacticoids can constitute between 20 and $100 \%$ (Gee 1989). Mouth gape widths differed between the studied fish species, being generally larger for $P$. minutus and
A. laterna and smaller for B. luteum (Piet et al. 1998). Consequently, harpacticoids as prey resource were also used by B. luteum at larger fish sizes.

\section{Conclusion}

Our results indicate that predation on meiofauna by solenette, goby, scaldfish and dab is highly selective for harpacticoids during all seasons, with a clear focus on species living in the uppermost sediment layers. It remains unclear whether the predation pressure induced by the fish species investigated here affects the meiofauna community in the study area. Several studies, both under laboratory and field conditions, found no or only small effects on meiofauna abundances by fish predation, since rapid turnover rates and short generation times of the meiofauna may compensate for the predation effects. Other factors, such as predatory meiofauna and macrofauna as well as physical properties, are more important in structuring meiofauna assemblages (Alheit and Scheibel 1982; Gee 1987; Coull 1990; Service et al. 1992; Aarnio 2000). Other authors have, however, demonstrated significant reductions in meiofaunal abundance in response to predation by fish (several flatfish species, gobiids and juvenile spot) (e.g. Bell and Coull 1978; Tito de Morais and Bodiou 1984; Fitzhugh and Fleeger 1985; Ellis and Coull 1989). They suggested that although fish predation alone does not control the distribution and overall abundance of meiofauna species, predator-prey interactions are important factors in controlling particular meiofaunal prey species. Therefore, we hypothesize that an intensive selective feeding of the four fish species on Pseudobradya spp. and Longipedia spp., combined with predation of other epibenthic predators (e.g. shrimps), might have an impact on the harpacticoid community, whereas predation impact on the meiofauna as a whole might be even negligible.

Acknowledgments The authors thank the captains and the crews of the FRV "Walther Herwig III" and the RV "Senckenberg" for their help with sampling. We would like to thank T. Schink, K. Tietje, S. Bem and B. Frank for their technical assistance in collecting and processing the samples. We would also like to thank M. Clément, T. Glatzel and P. Martínez Arbizu for their identification help on the harpacticoid copepods. Helpful comments of A. Dänhardt on an earlier version of the manuscript are acknowledged. We thank the Language Service of GRADE for correcting the English. The German Federal Environmental Foundation (DBU, Osnabrïck) is gratefully acknowledged for funding.

\section{References}

Aarnio K (2000) Experimental evidence of predation by juvenile flounder, Platichthys flesus, on a shallow water meiobenthic community. J Exp Mar Biol Ecol 246:125-138 
Aarnio K, Bonsdorff E (1993) Seasonal variation in abundance and diet of the sand goby Pomatoschistus minutus (Pallas) in a northern Baltic Archipelago. Ophelia 37(1):19-30

Alheit J, Scheibel W (1982) Benthic harpacticoids as a food source for fish. Mar Biol 70:141-147

Bayan B, Sever TM, Taskavak E (2008) Age, length-weight relationships and diet composition of scaldfish Arnoglossus laterna (Walbaum, 1792) (Pisces: Bothidae) in Izmir Bay (Aegean Sea). J Anim Vet Adv 7(8):924-929

Bell SS, Coull BC (1978) Field evidence that shrimp predation regulates meiofauna. Oecologia 35:141-148

Beukema JJ, Honkoop PJC, Dekker R (1998) Recruitment in Macoma balthica after mild and cold winters and its possible control by egg production and shrimp predation. Hydrobiologica 375(376): 23-34

Coull BC (1990) Are members of the meiofauna food for higher trophic levels? Trans Am Microsc Soc 109:233-246

Coull BC, Greenwood JG, Fielder DR, Coull BA (1995) Subtropical Australian juvenile fish eat meiofauna: experiments with winter whiting Sillago maculata and observations on other species. Mar Ecol Prog Ser 125:13-19

Darnaude AM, Harmelin-Vivien ML, Salen-Picard C (2001) Food portioning among flatfish (Pisces: Pleuronectiformes) juveniles in a Mediterranean coastal shallow sandy area. J Mar Biol Assoc UK 81:119-127

de Groot SJ (1971) On the interrelationships between morphology of the alimentary tract, food and feeding behaviour in flatfishes (Pisces: Pleuronectiformes). Neth J Sea Res 5:121-196

Ehrich S, Adlerstein S, Brockmann U, Floeter J, Garthe S, Kröncke I, Neumann H, Reiss H, Sell AF, Stein M, Stelzenmüller V, Stransky C, Temming A, Wegner G, Zaucke GP (2007) 20 years of the German small-scale bottom trawl survey (GSBTS): a review. Senck Marit 37(1):13-82

Ellis MJ, Coull BC (1989) Fish predation on meiobenthos: field experiments with juvenile spot Leiostomus xanthurus Lacépède. J Exp Mar Biol Ecol 130:19-32

Feller RJ, Coull BC, Hentschel BT (1990) Meiobenthic copepods: tracers of where juvenile Leiostomus xanthurus (Pisces) feed? Can J Fish Aquat Sci 47:1913-1919

Fitzhugh GR, Fleeger JW (1985) Goby (Pisces: Gobiidae) interactions with meiofauna and small macrofauna. Bull Mar Sci 36(3): 436-444

Fonds M (1973) Sand gobies in the Dutch Wadden Sea (Pomatoschistus, Gobiidae, Pisces). Neth J Sea Res 6:417-478

Gee JM (1987) Impact of epibenthic predation on estuarine intertidal harpacticoid copepod populations. Mar Biol 96:497-510

Gee JM (1989) An ecological and economic review of meiofauna as food for fish. Zool J Linn Soc 96:243-261

Gibson RN, Ezzi IA (1980) The biology of the scaldfish, Arnoglossus laterna (Walbaum) on the west coast of Scotland. J Fish Biol $17: 565-575$

Govaere JCR, van Damme D, Heip C, de Coninck LAP (1980) Benthic communities in the Southern Bight of the North Sea and their use in ecological monitoring. Helgol Meeresunters 33: 507-521

Heip C, Craeymeersch JA (1995) Benthic community structures in the North Sea. Helgol Meeresunters 49:313-328

Heip C, Huys R, Alkemade R (1992) Community structure and functional roles of meiofauna in the North Sea. Neth J Aqua Ecol 26(1):31-41

Hicks GRF (1984) Spatio-temporal dynamics of a meiobenthic copepod and the impact of predation disturbance. J Exp Mar Biol Ecol 81:47-72

Hicks GRF, Coull BC (1983) The ecology of marine harpacticoid copepods. Ocean Mar Biol Ann Rev 21:67-175
Hinz H, Kröncke I, Ehrich S (2005) The feeding strategy of dab Limanda limanda in the southern North Sea: linking stomach contents to prey availability in the environment. J Fish Biol 67:125-145

Hoghue EW, Carey AG (1982) Feeding ecology of 0-age flatfish at a nursery ground on the Oregon coast. Fish Bull 80:555-564

Huys R, Herman PMJ, Heip CHR (1986) Seasonal fluctuations in vertical distribution and breeding activity of a subtidal harpacticoid community in the southern Bight, North Sea. Neth J Sea Res 20(4):375-383

Huys R, Herman PMJ, Heip CHR, Soetaert K (1992) The meiobenthos of the North Sea: density, biomass trends and distribution of copepod communities. ICES J Mar Sci 49:23-44

Hyslop EJ (1980) Stomach contents analysis: a review of methods and their application. J Fish Biol 17:415-429

ICES (2009) Manual for the offshore beam trawl surveys. Working group on beam trawl surveys, p 30. http://www.ices.dk/Documents/ Manuals/WGBEAM_Manual.pdf. Revision 1.2 June 2009

Ivlev VS (1962) Experimental ecology of the feeding of fishes. Yale University Press, New Haven

Jennings S, Lancaster J, Woolmer A, Cotter J (1999) Distribution, diversity and abundance of epibenthic fauna in the North Sea. J Mar Biol Assoc UK 79:385-399

Juario JV (1975) Nematode species composition and seasonal fluctuation of a sublittoral meiofauna community in the German Bight. Veröff Inst Meeresforsch Bremerh 15:283-337

Knust R (1986) Food ecology of North Sea dab (Limanda limanda). 1. Seasonal changes in food uptake and condition in the German Bight and on the Dogger Bank. Arch Fish Mar Res 44:1-123

Kovačić M (2001) The biology of Roule's goby in Kvarner area, northern Adriatic Sea. J Fish Biol 59:795-809

Kovačić M (2007) Diet of Gobius vittatus (Gobiidae) in the northern Adriatic Sea. Vie Milieu 57(1):27-33

Kovačić M, la Mesa M (2008) Feeding ecology of de Buen's goby Buenia affinis, in the Kvarner area (Adriatic Sea). Via Milieu Life Environ 58(3/4):249-256

Magnhagen C, Northcote TG, Gregory RS (2007) Diet differentiation in three species of juvenile salmon (Oncorhynchus spp.) in Estuarine tidal channels and laboratory experiments. In: Canadian technical report of fisheries and aquatic sciences, vol 2758, p 20

McCall JN (1992) Source of harpacticoid copepods in the diet of juvenile starry flounder. Mar Ecol Prog Ser 86:41-50

McIntyre AD, Warwick RM (1984) Meiofauna techniques. In: Holme NA, McIntyre AD (eds) Methods for the study of marine benthos, 2nd edn. Blackwell Scientific, Oxford, pp 217-244

Nelson AL, Coull BC (1989) Selection of meiobenthic prey by juvenile spot (Pisces): an experimental study. Mar Ecol Prog Ser 53:51-57

Nottage AS, Perkins EJ (1983) The biology of solenette, Buglossidium luteum (Risso), in the Solway Firth. J Fish Biol 22:21-27

Olafsson E, Elmgren R (1997) Seasonal dynamics of sublittoral meiobenthos in relation to phytoplankton sedimentation in the Baltic Sea. Estuar Coast Shelf Sci 45:149-164

Piet GJ, Pfisterer AB, Rijnsdorp AD (1998) On factors structuring the flatfish assemblage in the southern North Sea. J Sea Res 40: $143-152$

Reiss H, Kröncke I (2004) Seasonal variability of infaunal community structures in three areas of the North Sea under different environmental conditions. Estuar Coast Shelf Sci 65:253-275

Rudnick DT, Elmgren R, Frithsen JB (1985) Meiofaunal prominence and benthic seasonality in a coastal marine ecosystem. Oecologia 67:157-168

Schoener TW (1971) Theory of feeding strategies. Ann Rev Ecol Syst 11:369-404 
Scholz DS, Matthews LA, Feller RJ (1991) Detecting selective digestion of meiobenthic prey by juvenile spot Leiostomus xanthurus (Pisces) using immunoassays. Mar Ecol Prog Ser 72:277-293

Schückel S, Sell AF, Kröncke I, Reiss H (2011) Diet composition and resource partitioning in two small flatfish species in the German Bight. J Sea Res 66:195-204

Schückel S, Sell AF, Kröncke I, Reiss H (2012) Diet overlap among flatfish species in the southern North Sea. J Fish Biol 80: 2571-2594

Sedlacek L, Thistle D (2006) Emergence on the continental shelf: differences among species and between microhabitats. Mar Ecol Prog Ser 311:29-36

Service SK, Feller RJ, Coull BC, Woods R (1992) Predation effect of three fish species and a shrimp on macrobenthos and meiobenthos in microcosms. Estuar Coast Shelf Sci 34:277-293

Sibert JR (1979) Detritus and juvenile salmon production in the Nanaimo estuary: II. Meiofauna available as food to juvenile Chum salmon (Oncorhynchus keta). J Fish Res Board Can $36: 497-503$
Sogard SM (1984) Utilization if meiofauna as food source by a grassbed fish, the spotted dragonet Callionymus pauciradeldiatus. Mar Ecol Prog Ser 17:183-191

Spieth HR, Möller T, Ptatscheck CH, Kazemi-Dinan A, Traunspurger W (2010) Meiobenthos provides food resource for young cyprinids. J Fish Biol 78:138-149

Thistle D (2003) Harpacticoid copepod emergence at a shelf site in summer and winter: implications for hydrodynamic and mating hypotheses. Mar Ecol Prog Ser 248:177-185

Tipton K, Bell SS (1988) Foraging patterns of two syngnathid fishes; importance of harpacticoid copepods. Mar Ecol Prog Ser 47:31-43

Tito de Morais L, Bodiou JY (1984) Predation on meiofauna by juvenile fish in a Western Mediterranean flatfish nursery ground. Mar Biol 82:209-215

Warwick RM, Price R (1979) Ecological and metabolic studies on free-living nematodes from an estuarine mud-flat. Est Coast Mar Sci 9:257-271

Zander CD (1979) On the biology and food of small-sized fish from the North and Baltic Sea areas. II Investigation of a shallow stony ground off MØN, Denmark. Ophelia 18(2):179-190 